\title{
TRANSFORMASI PEMIKIRAN DAN GERAKAN ISLAM INDONESIA KONTEMPORER
}

\author{
Muhammad Rusydy \\ Fakultas Ushuluddin IAIN STS Jambi \\ Email: drmuhammadrusydi@gmail.com
}

\begin{abstract}
The transformation of the contemporary era Indonesian Islam is a description of the development of thinking and the Islamic movement in Indonesia in modern times. This article is going to discuss the development or "transformation" Islam Indonesia since the eve of independence until the reform period. This article found that the transformation of Islam in Indonesia has developed advanced past the ups and downs. In the early days of the Japanese occupation obtain the freedom of Muslims to perform the transformation of Islam in politics and society. But ahead of the independence of Indonesia situation is reversed, the role of Muslims transformation into a narrow compared with the role that obtained by other groups, especially among secular nationalists.
\end{abstract}

\section{Abstrak}

Transformasi Islam era kontemporer Indonesia adalah deskripsi perkembangan pemikiran dan gerakan Islam di Indonesia pada zaman modern. Artikel ini hendak membahas perkembangan atau "transformasi" Islam Indonesia sejak masa menjelang kemerdekaan hingga masa masa reformasi. Artikel ini menemukan bahwa transformasi Islam pada masa mutakhir Indonesia mengalami perkembangan yang pasang surut. Pada masa awal pendudukan Jepang umat Islam memperoleh kebebasa untuk melakukan transformasi Islam dalam bidang politik dan kemasyarakatan. Namun menjelang kemerdekaan Indonesia keadaan menjadi terbalik, peran trasformasi umat Islam menjadi sempit dibanding dengan peran yang diperoleh oleh golongan lainnya khususnya kalangan Nasionalis sekuler.

Kata Kunci: Islam Indonesia, Transformasi, Era Kontemporer. 


\section{Pendahuluan}

Membahas tentang dinamika trasnformasi Islam di Indonesia pada masa kontemporer sama artinya dengan membahas tentang kemungkinan dan citra Islam Indonesia. Setiap orang tentu mempunyai pikiran yang berbeda-beda karena setiap orang mempunyai kerangka yang tidak sama dalam melihat keadaan atau realitas Islam masa kontemporer Indonesia sesuai dengan sudut pandangnya masing-masing. Ada yang melihat secara optimis dan ada pula yang melihat secara pesimis transformasi Islam di Indonesia. Hal ini tergantung bagaimana setiap orang mempunyai persepsi mengenai situasi yang sedang berlangsung dibanding situasi sebelumnya.

Setiap orang mempunyai persepsi yang berbeda-beda terhadap suatu keadaan yang memberi pengaruh terhadap bangunan konseptual yang kemudian akan mempengaruhi tindakan transformasi Islam baik sebagai individu maupun kelompok. Maka seandainya pada tataran konseptual tidak ada upaya saling pendekatan maka tidak akan lahir kebersamaan tindakan kolektif ke arah yang sama dalam transformasi Islam. Bisa saja dalam memandang transformasi Islam banyak orang yang menggunakan bahasa dan istilah yang sama misalnya tajdid atau ukhuwah Islamiah, namun setiap orang justeru mempunyai rancang bangun keinginan transformasi Islam yang berbeda. ${ }^{1}$

Memang terkadang tampak gejala bahwa Islam kehilangan idealisme dari setiap orang, padahal idealisme itu dapat memberi referensi ke arah transformasi Islam yang ingin dituju. Ini menimbulkan kesan seolah-olah kehidupan sebagian umat Islam memperlihatkan dualisme. Intensitas transformasi Islam menjadi begitu romantis namun belum tentu membuahkan hasil yang bersifat individual apalagi yang bersifat sosial. Kehidupan keberagamaan sepertinya hanya sekedar rutinitas dan ukuran-ukurannya hanya bersifat permukaan. Karena itu kemudian agama dalam hal ini Islam hanya menjadi alat legitimasi penting kelompok tertentu terutama penguasa politik dan ekonomi. Selanjutnya mereka akan menguasai orang-orang yang terkungkung dalam kondisi struktur kehidupannya dari aspek politik, sosial, ekonomi, pendidikan, dan sebagainya.

${ }^{1}$ Moeslim Abdurrahman, Islam Transformatif (Jakarta: Pustaka Firdaus, 1997), 2.

36 | TAJDID vol. XVI, No. 1, Januari - Juli 2017 
Atas dasar ini maka dalam transformasi Islam di era kontemporer Indonesia diharapkan agar dapat memberikan pencerahan atau bahkan pembebasan terhadap umat Islam. Dengan demikian peran Islam tidak terbatas hanya dapat mentransformasikan penyelamatan individu yang menekankan intesitas ritual dengan tema transformasi yang hanya dihiasi dengan janji-janji Tuhan, tanpa menyentuh permasalahan yang menjadi realitas sehari-hari, tetapi juga dapat mentransformasikan penyelematan yang bersifat kolektif sosial. Dalam kaitan transformasi Islam ini akan dikemukakan dibawah meskipun menurut orang lain agak subjektif, namun betapapun bentuk subjektivitas itu, tetap merupakan suatu keharusan untuk mendiskusikan berbagai persepsi agar transformasi Islam di era Indonesia sekarang mendekati makna dan tujuan Islam yang sebenarnya. ${ }^{2}$

\section{Transformasi Islam Menjelang Kemerdekaan Indonesia}

Berawal dari gerakan modern Islam yang merupakan jawaban yang ditujukan terhadap krisis yang dihadapi oleh umat Islam pada masanya. Gerakan modern ini bertitik tolak dari kemunculan gerakan Wahabi yang reformis dan puritanis di Saudi Arabia. Gerakan modern ini merupakan sarana yang menyiapkan jembatan ke arah pembaharuan Islam abad kontemporer yang bersifat intelektual dan global. Lalu gerakan ini terkristal oleh Jamaluddin al-Afghani (w. 1897) yang menyuarakan solidaritas pan-Islam dan pertahanan terhadap inperialisme Eropa. Pan-Islam adalah persatuan umat Islam seluruh dunia dengan kembali kepada Islam dalam suasana kontemporer.

Gerakan yang lahir di Timur Tengah ini memberikan pengaruh besar kepada kebangkitan Islam era kontemporer di Indonesia. Bermula dari pembaharuan pemikiran dan pendidikan Islam di Minangkabau yang disusul oleh pembaharuan pendidikan yang dilakukan oleh masyarakat Arab di Indonesia. Kebangkitan Islam semakin berkembang dengan terbentuknya beberapa organisasi sosial misalnya SDI (Sarekat Dagang Islam) di Bogor tahun 1909 dan Solo tahun 1911, Muhammadiyah di Yogyakarta tahun 1912, Persis (Persatuan Islam) di Bandung tahun 1920, NU (Nahdhatul Ulama) di Surabaya tahun 1926, dan Perti (Persatuan Tarbiyah Islamiyah) di

${ }^{2}$ Moeslim Abdurrahman, Islam Transformatif, 3.

TAJDID Vol. XVI, No. 1, Januari - Juli $2017 \mid 37$ 
Candung, Bukit Tinggi tahun 1930. ${ }^{3}$ Jadi, gerakan pembaharuan yang muncul di Timur Tengah khususnya di Mesir dan Saudi Arabia mendorong lahirnya gerakan serupa di Indonesia. Lahirnya gerakan pembaharuan ini menjadi faktor lahirnya kebangkitan Islam yang ditandai dengan lahirnya berbagai organisasi sosial keagamaan Islam. Lahirnya berbagai organisasi sosial keagamaan sebagai pertanda tumbuhnya nasionalisme di Indonesia.

Nasionalisme dalam pengertian politik baru muncul setelah Samanhudi menyerahkan kepemimpinan SDI kepada Tjokroaminoto pada bulan Mei 1912. Tjokroaminoto mengubah nama SDI menjadi SI (Sarekat Islam) dan mengubah sifat organisasi ini dan memperluas gerakannya. ${ }^{4}$ Sejak ini maka muncul semangat nasionalisme Indonesia. Sebagai pelopor nasionalisme Indonesia, SI merupakan organisasi politik besar yang merekrut anggota-anggotanya dari berbagai kelas dan aliran yang ada di Indonesia. Waktui itu ideologi bangsa adalah persatuan dan anti kolonialisme. Semua komponen ingin mencapai kemerdekaan, bebas dari kekuasaan Belanda.

Belakangan tokoh-tokoh dan organisasi-organisasi pergerakan mulai berbeda taktik dan program. Golongan revolusioner berhadapan dengan golongan moderat, begitupula politik koperasi tidak sejalan dengan dengan politik non koperasi. Puncak perbedaan ini terjadi di dalam SI sendiri. Di mana di dalam SI muncul kekuatan baru dengan ideologinya sendiri, yakni Komunisme. Pemisahan secara nyata dan besar-besaran antara SI dan Komunisme yang kemudian bertransformasi menjadi PKI terjadi pada tahun 1923. Banyak kalangan pergerakan yang kecewa terhadap perpecahan itu. Namun mereka lebih kecewa karena perpecahan itu menunjukkan adanya ideologi masing-masing yang berbeda tajam. Sejak masa itu SI dengan tegas menyatakan bahwa ideologinya adalah Islam. Nasionalisme yang diperjuangkannya ialah nasionalisme yang berdasarkan ajaran-ajaran Islam.

Kekecewaan itu beralasan karena untuk mencapai kemerdekaan, diperlukan kesatuan dan persatuan. Reaksi yang muncul bukan untuk mempersatukan kubu yang bertikai. Pihak yang kecewa bahkan mendirikan kekuatan politik baru yang terlepas dari Komunisme dan

3Deliar Noer, Gerakan Modern Islam di Indonesia 1900-1942 (Jakarta: LP3ES, 1980), 23.

${ }^{4}$ Almelz, (ed.), HOS Tjokroaminoto Hidup dan Perjuangan, (Jakarta: Bulan Bintang, 1952), 94.

38 | TAJDID Vol. XVI, No. 1, Januari - Juli 2017 
Islam. Maka kemudian secara berturut-turut berdiri PNI (Partai Nasional Indonesia) tahun 1927, Partindo (Partai Indonesia), dan Pendidikan Nasional Indonesia Baru tahun 1931. Dengan demikian terdapat tiga kekuatan politik yang mencerminkan tiga aliran ideologi yaitu Islam, Komunisme, dan Nasionalisme "sekuler", Perpecahan di antara ketiga golongan itu disebabkan oleh pendidikan yang mereka terima yang bersifat Barat. Pendidikan Belanda memang diusahakan agar menimbulkan emansipasi dari agama di kalangan pelajar, sebab agama dianggap terutama yang menimbulkan pergolakan politik di kalangan rakyat Indonesia. ${ }^{5}$ Menurut pendapat lain bahwa perpecahan itu merupakan kelanjutan wajar dari latar belakang budaya masyarakat khususnya Jawa. Proses Islamisasi damai di Indonesia yang mengompromikan ajaran Islam dengan nilai-nilai budaya melahirkan tiga golongan yaitu santri, abangan, dan priyayi. Ideologi Islam didukung oleh golongan santri, Komunisme didukunga oleh golongan abangan, dan Nasionalisme "sekuler" didukung oleh golongan priyayi ${ }^{6}$

Dalam suasana konflik semacam itu maka SI semakin merosot semakin merosot dari hari ke hari. Sebaliknya Partai Nasionalis "sekuler" berkembang dengan pesat. Tingkat pendidikan dan kemampuan merumuskan realitas dari kalangan kaum nasionalis tampak lebih baik dari pada SI yang mewakili Islam. Apalagi setelah Tjokroaminoto wafat, SI beberapa kali mengalami perpecahan, misalnya dengan munculnya Penyadar di bawah Agus Salim dan M. Roem (1936) serta Komite Kebenaran PSII di bawah Kartosuwiryo (1939) yang mengakibatkan SI semakin kehilangan pamor.

Kemerosotan yang dialami oleh beberapa Partai Islam seakan mendapatkan daya kembali setelah Jepang menggantikan posisi Belanda. Jepang berusaha mengakomodasi dua kekuatan, Islam dan Nasionalis "sekuler". Jepang berpendapat bahwa organisasi-organisasi Islam sebenarnya yang mempunyai massa yang patuh. Maka dengan pendekatan agama penduduk Indonesia dapat dimobilisasi. Oleh karena itu, kalau organisasi-organisasi non keagamaan dibubarkan, organisasi-organisasi besar Islam misalnya Muhammadiyah, NU, Persyarikatan Ulama Majalengka, MIAI (Majelis Islam A’la Indonesia)

${ }^{5}$ Deliar Noer, Gerakan Modern Islam di Indonesia 1900-1942 (Jakarta: LP3ES, 1980), 39 64.

${ }^{6}$ Cliffford Geerts, Santri Abangan dan Priyayi (Jakarta: Pustaka Jaya, 1980),

TAJDID Vol. XVI, No. 1, Januari - Juli 2017 | 39 
yang dilanjutkan dengan Masyumi (Majelis Syuro Muslimin Indonesia) diperbolehkan kembali untuk meneruskan kegiatannya. Permohonan Masyumi pun diterima oleh Pemerintah Pendudukan Jepang untuk mendirikan barisan Hizbullah, sebuah wadah kemilitertan bagi kaum santri. Bahkan tentara PETA (Pembela Tanah Air) didominasi oleh golongan santri.

Bagi golongan Nasionalis "sekuler" dibentuk lembaga-lembaga baru misalnya Gerakan Tiga A (Nippon cahaya Asia, Nippon pelindung Asia, Nippon pemimpin Asia) yang didirikan pada bulan Mei 1942 dan Putera (Pusat Tenaga Rakyat) yang didirikan pada bulan Maret 1943. Satu bulan berikutnya baru dimulai pengembangan Putera yang diketuai oleh Soekarno dan dibantu oleh M. Hatta, Ki Hadjar Dewantara, dan K.H. Mas Mansur. Mereka itu yang dikenal sebagai empat serangkai pemimpin bangsa. Dari empat serangkai itu dapat dilihat bahwa tokoh Nasionalis 'sekuler" lebih dominan dalam gerakan kebangsaan dari pada golongan Islam. Jepang kemudian menjanjikan kemerdekaan untuk Indonesia dengan mengeluarkan maklumat pada bulan April 1945 tentang pembentukan BPUPKI (Badan Penyelidik Usaha-usaha Persiapan Kemerdekaan Indonesia). Berbeda dengan sebelumnya di mana umat Islam memperoleh ruang partisipasi yang besar dari Jepang, sekarang keanggotaan dalam BPUPKI didominasi oleh kalangan Nasionalis "sekuler" yang kala itu biasa disebut Golongan Kebangsaan. Di dalam Badan ini Soekarno mencetuskan ide Pancasila. Meskipun di dalam rumusan Pancasila itu terdapat prinsip Ketuhanan, namun ada pandangan bahwa negara pada dasarnya dipisahkan dari agama. ${ }^{7}$

\section{Transformasi Islam Era Revolusi}

Pada masa proklamasi kemerdekaan Indonesia pada tahun 1945, Piagam Jakarta tidak digunakan. Soekarno dan M. Hatta justeru membuat teks proklamasi yang singkat karena ditulis secara tergesagesa. Perlu diketahui bahwa menjelang kemerdekaan, setelah Jepang dengan terpaksa kalah dari tentara sekutu, BPUPKI ditingkatkan statusnya menjadi PPKI (Panitia Persiapan Kemerdekaan Indonesia). Berbeda dengan BPUPKI yang anggotanya hanya berasal dari Pulau Jawa, PPKI merupakan perwakilan daerah seluruh Indonesia yang aggotanya berasal dari seluruh Indonesia. Prubahan in menyebabkan banyak anggota BPUPKI yang tidak masuk jadi anggota PPKI.

7John D. Legge, Soekarno Sebuah Otobiografi Politik (Jakarta: S. H., 1985). 72.

40 | TAJDID Vol. XVI, No. 1, Januari - Juli 2017 
Persentase perbandingan antara Nasionalis "sekuler" dan Islam pun merosot tajam.

Setelah kemerdekaan dicapai, M. Hatta dalam sidang PPKI dapat meyakinkan anggotanya bahwa hanya konstitusi "sekuler" yang mempunyai peluang untuk diterima oleh seluruh bangsa Indonesia. Tujuh kata dalam anak kalimat yang tercantum dalam sila pertama Pancasila dengan segala konsekuensinya harus dihapuskan dari konstitusi. Bahkan Kantor Urusan Agama sebagaimana yang diperoleh umat Islam pada masa pendudukan Jepang ditolak oleh PPKI. ${ }^{8}$ Oleh golongan Nasionalis "sekuler" bahwa keputusan itu dianggap sebagai gentlemen's agreement kedua yang menghapuskan Piagam Jakarta gentlemen's agreement pertama. Sementara itu, keputusan yang sama dipandang oleh golongan Islam sebagai mengkhianati gentlemen's agreement itu sendiri. Golongan Islam mengetahui bahwa Indonesia merdeka yang mereka perjuangkan dengan penuh pengorbanan tidak tercapai. Oleh karena itu, dapat dibayangkan betapa kecewanya golongan Islam.

Dengan demikian jelas bahwa keputusan tentang penghapusan tujuh kata dari Piagam Jakarta itu sama sekali tidak menyelesaikan konflik ideologi yang telah berlangsung sejak masa sebelum kemerdekaan. Golongan Islam harus menerima kenyataan tersebut karena mereka menyadari bahwa masa revolusi bukan waktu yang tepat untuk mendesak terlaksananya cita-cita Islami mereka. Apalagi Soekarno dan M. Hatta menekankan sifat kesementaraan UUD 45 yang diputuskan pada tanggal 17 Agustus 1945. Soekarno menyatakan bahwa dalam suasana yang kondusif nanti dapat dibuat UUD yang lebih lengkap dan sempurna. ${ }^{9}$ Hal yang melegakan umat Islam adalah keputusan KNIP (Komite Nasional Indonesia Pusat) yang menggantikan PPKI. Dalam sidang KNIP pada tanggal 25-27 Nopember 1945 di bawah pimpinan Syahrir, KNIP membahas usulan agar dalam Indonesia merdeka soal-soal keagamaan ini diurus oleh suatu kementerian tersendiri dan tidak menjadi bagian dari tanggung jawab Kementerian Pendidikan. Keputusan tentang Kementerian Agama ini merupakan konsesi kepada umat Islam yang bersifat kompromi, kompromi antara teori "sekuler" dan teori Islam. ${ }^{10}$

${ }^{8}$ B.J. Boland, Pergumulan Islam di Indonesia (Jakarta: Grafitipers, 1985), 110.

${ }^{9}$ Endang Saifuddin Anshari, Piagam Jakarta 22 Juni 1945, (Bandung: Pustaka, 1983), 54.

${ }^{10}$ Endang Saifuddin Anshari, Piagam Jakarta, 54.

TAJDID vol. XVI, No. 1, Januari - Juli $2017 \mid 41$ 
Umat Islam memang gigih memperjuangkan kemerdekaan Indonesia dari agresi Belanda yang datang dengan bantuan tentara sekutu untuk kembali menjajah Indonesia. Tokoh-tokoh Islam duduk dalam beberapa posisi penting di dalam Kabinet atau kepemimpinan perjuangan pisik dan diplomatik. Sementara rakyat terlibat langsung dalam perjuangan pisik. Para ulama di kampung-kampung menyerukan perang jihad. Rakyat dan apalagi umat Islam berjuang dengan jihad sampai kemerdekaan penuh Indonesia tercapai.

Meskipun Departemen Agama dibentuk, namun tidak meredakan konflik ideologi pada masa sesudahnya. Setelah Wakil Peresiden ketika itu mengeluarkan maklumat tentang diperbolehkannya mendirikan partai-partai politik, tiga kekuatan politik sebelumnya dengan ideologi masing-masing mencuat kembali. Pada tanggal 17 Nopember 1945 Masyumi (Majelis Syura Muslimin Indonesia) berdiri sebagai wadah aspirasi politik umat Islam. Pada tanggal 17 Desember 1945 Partai Sosialis yang berhaluan Marxis dan pada tanggal 29 Januari 1946 Partai Nasional Indonesia yang mewadahi kaum nasionalis "sekuler" pun muncul. Beberapa Partai Politik yang berdiri sesudah itu pun dapat dikelompokkan ke dalam tiga aliran utama ideologi sebagaimana disebutkan di atas. Di samping Masyumi, Partai-partai Islam lainnya ialah PSII (Partai Sarikat Islam Indonesia) yang memisahkan diri dari Masyumi pada tahun 1947, Perti (Persatuan Tarbiyah Islamiyah), dan NU yang keluar dari Masyumi pada tahun 1952. Dalam masa revolusi, konflik ideologi tidak begitu jelas, tetapi dapat dilihat dari pergantian anggota Kabinet yang sering terjadi. Baru setelah Pemilihan Umum pertama pada tahun 1955, di dalam Konstituante hasil Pemilihan Umum, dialog ideologi kembali muncul secara terbuka sebagaimana yang terjadi dalam BPUPKI sebelumnya. ${ }^{11}$

Tiga kekuatan ideologi; Islam, Nasionalis, dan Sosialis, sebagaimana disebutkan di atas memunculkan tiga alternatif Dasar Negara yaitu Islam, Pancasila, dan Sosial Ekonomi, namun dalam perjalanan sidang-sidang Konstituante itu, perdebatan ideologi mengenai Dasar Negara terkristal menjadi dua yaitu Islam dan Pancasila. Dalam Pemilihan Umum tahun 1955 tidak ada Partai Politik baik dengan ideologi Islam, atau Nasionalis, maupun Sosialis

${ }^{11}$ Deliar Noer, Partai-partai Islam di Pentas Nasional, (Jakarta: Grafitipers, 1987), 39.

42 | TAJDID vol. XVI, No. 1, Januari - Juli 2017 
yang menang secara mutlak. Yang ada adalah suatu perimbangan kekuatan yang mengharuskan adanya kompromi dalam bidang politik.

Usaha Partai-partai Islam untuk menegakkan Islam sebagai ideologi Negara di dalam Konstituante mengalami jalan buntu. Demikian juga Pancasila yang dipandang oleh sebagian tokoh umat Islam waktu itu sebagai milik kaum "anti Islam". Memang kesempatan bagi Konstituante untuk menyelesaikan tugasnya masih tersisa, namun tugasnya diakhiri dengan dikeluarkannya Dekrit Peresiden 1959. Konstituante dinyatakan bubar dan UUD 1945 dinyatakan berlaku kembali. Dalam konsideran Dekrit Peresiden 1945 disebutkan bahwa Piagam Jakarta menjiwai dan merupakan rangkaian kesatuan dengan UUD 1945.12 Jelas, Dekrit Peresiden 1945 memberikan jalan tengah. Namun Dekrit Peresiden 1945 itu sendiri menandai dimulainya suatu era baru, Demokrasi Terpimpin. Ini membawa kehidupan demokrasi dalam bernegara terancam dan berada dalam krisis. Masyumi yang berpegang erat pada Konstitusi, dibubarkan oleh Soekarno pada bulan Agusuts 1960.

\section{Transformasi Islam Era Demokrasi Terpimpin}

Setelah Masyumi dibubarkan, Partai-partai Islam tinggal NU, PSII, dan Perti. Partai-partai ini, sebagaimana Partai-partai lain, mulai menyesuaikan diri dengan keinginan Soekarno yang didukung oleh dua pihak yang sedang berseberangan yaitu ABRI dan PKI. Langkah akomodatif Partai-partai Islam itu bahkan disandarkan pada Agama (Islam). Al-Qur'an terkadang digunakan sebagai dasar pijakan oleh mereka. NU sebelumnya pernah memberikan gelar $W$ aly al-'Amr alDharury bi al-Syaukah kepada Soekarno. Untuk menyenangkan hati Soekarno kemudian IAIN Syarif Hidayatullah Jakarta pun memberikan gelar Doktor Kehormatan (Dr.HC) kepadanya dalam Ilmu Ushuluddin dengan Promotor K.H. Saifuddin Zuhri. K.H. Saifuddin Zuhri sebagai pimpinan NU, diberi banyak peran oleh Soekarno dalam Pemerintahan Demokrasi Terpimpin. Mungkin langkah akomodatif Partai-partai Islam ini mempunyai tujuan agar nasibnya berbeda dengan Masyumi, di mana tokoh-tokohnya diintimidasi oleh golongan yang pro Soekarno.

Walaupun Partai-partai Islam itu mengadakan penyesuaian dengan kebijakan Soekarno, namun secara keseluruhan peran Partai-

${ }^{12}$ Endang Saifuddin Anshari, Piagam Jakarta 22 Juni 1945, (Bandung: Pustaka, 1983), 43.

TAJDID Vol. XVI, No. 1, Januari - Juli $2017 \mid 43$ 
partai Islam tersebut mengalami kemerosotan. Tidak ada jabatan menteri dengan posisi penting yang diserahkan kepada Islam sebagaimana yang terjadi pada masa Demokrasi Parlementer. Satusatunya kepentingan Islam yang diakomodir adalah Keputusan MPRS tahun 1960 yang memberlakukan pengajaran Agama (Islam) di Universitas dan Perguruan Tinggi. ${ }^{13}$ Jadi, pada masa ini umat Islam selalu berusaha untuk menyesuaikan diri dengan kebijakan pemerintah di bawah Peresiden Soekarno, namun justeru perannya diperkecil yang ditandai dengan tiadanya peran penting yang diberikan kepada mereka. Sehingga umat Islam semakin tidak punya peran apa-apa.

Di masa Demokrasi Terpimpin ini Soekarno kembali menyuarakan ide lamanya yakni Nasakom (Nasionalisme, Agama, Komunisme). Ide ini suatu pemikiran yang ingin menyatukan Nasionalisme "sekuler", Islam, dan Komunisme. Akan tetapi ide ini dilaksanakan dengan cara Soekarno sendiri. Peranan Partai-partai mengalami erosi, kecuali PKI yang tetap memainkan peranan yang penting. Pancasila pun ditafsirkan sesuai dengan pemikirannya. Masa ini, karena peranan didominasi oleh PKI, memendam ketegangan antara Islam dan Komunisme. Ketidakpuasan juga terjadi di kalangan banyak golongan Nasionalis "sekuler" dan ABRI. Masa Demokrasi Terpimpin tersebut berakhir dengan gagalnya Gerakan 30 September 1965. Umat Islam bersama ABRI dan golongan lainnya yang pro Republik, bekerjasama untuk menumpas gerakan itu. ${ }^{14}$ Ide Nasakom dari Soekarno merupakan pemikiran lama. Ketika diinisiasi oleh Soekarno untuk dimunculkan kembali justeru dapat dibaca sebagai alat bagi PKI untuk memperluas pengaruh dan kekuasaannya. Memang dapat dilihat bahwa pada satu sisi mempersempit peran bangsa Indonesia khususnya umat Islam, namun pada sisi yang lain memberikan keleluasaan kepada PKI. Sehingga setelah PKI merasa kuat kemudian mengadakan pemberontakan yang dikenal dengan G30S PKI.

\section{Transformasi Islam Era Orde Baru}

Setelah Orde Lama jatuh, kepemimpinan Indonesia berada di tangan Orde Baru. Tumbangnya Orde Lama memberikan harapan baru kepada umat Islam. Namun belakangan kekecewaan baru pun

${ }^{13}$ Taufik Abdullah, (ed.), Sejarah Ummat Islam Indonesia, (Jakarta: MUI, 1991), 405.

${ }^{14}$ Taufik Abdullah, (ed.), Sejarah Ummat Islam Indonesia, (Jakarta: MUI, 1991), 405. 
muncul. Umat Islam merasa bahwa meskipun musuh bebuyutannya yaitu PKI telah tumbang, namun kenyataan yang berkembang tidak seperti yang diharapkan. Bahkan tokoh-tokoh umat Islam juga tidak diizinkan untuk aktif dalam Partai Muslimin Indonesia (Parmusi) yang didirikan kemudian. ${ }^{15}$ Jadi, penguasa Orde Baru mempunyai sikap kepemimpinan yang sama dengan Orde Lama terhadap umat Islam. Hal mana Orde Baru kelihatannya tetap tidak memberikan kebebasan yang memadai kepada umat Islam.

Sejak semula Orde Baru sudah mencanangkan pembaharuan dalam sistem politik. Pada tahun 1966 Peresiden Soeharto, pengganti Soekarno, menyampaikan amanat di hadapan sidang DPRGR tentang RUU Kepartaian, RUU Pemilu, dan RUU Susunan MPR; DPR; serta DPRD. Kemudian RUU Pemilu dan RUU Susunan MPR, DPR, serta DPRD disahkan pada tahun 1969. Sementara itu RUU Kepartaian terhenti. Pada bulan Maret 1970 Fraksi-frakasi Partai Politik (Parpol) di DPR dikelompokkan. Pada tahun 1973 semua Parpol-parpol dofusikan ke dalam dua partai yaitu PPP (Partai Persatuan Pembangunan) dan PDI (Partai Demokrasi Indonesia). Pada tahun 1975 RUU kepartaian baru disahkan. Penataan kehidupan kepartaian berikutnya adalah penetapan Asas Tunggal Pancasila sebagai dasar Ideologi untuk semua Parpol, Golkar, dan semua Organisasi Kemasyarakatan. Sejak itu tidak ada lagi asas, ciri, dan ideologi khusus Islam. ${ }^{16}$ Dengan demikian sejak itu maka sebenarnya penetapan Asas Tunggal Pancasila sebagai asas Ideologi bagi Parpol dan Ormas terutama bagi PPP merupakan awal dari era baru peran Islam dalam kehidupan berbangsa dan bernegara.

Berkenaan dengan peran Islam, ide tentang peran Islam sebagai dasar negara Indonesia secara terus menerus dan konsisten selalu ditolak. Bahkan Partai-partai Islam di pentas kontestasi selalu mengalami kekalahan, baik dalam pentas politik maupun dalam pemilu, sejak dari masa penjajahan sampai masa kemerdekaan. Malah dengan pembaharuan politik negara bangsa pada era modern ini Partai-partai berideologi Islam pun lenyap.

Menjelang Pancasila diputuskan dalam Sidang Umum MPR pada tahun 1983 sebagai satu-satunya asas bagi Partai Politik, banyak kalangan yang melontarkan penolakan. Suara penolakan itu semakin

${ }^{15 B}$ B.J. Boland, Pergumulan Islam di Indonesia, terjemahan, (Jakarta: Grafitipers, 1985), 157-162.

${ }^{16}$ Yusril Ihza Mahendra, Panjimas, No, 284.

TAJDID Vol. XVI, No. 1, Januari - Juli 2017 | 45 
tajam ketika Pancasila benar-benar ditetapkan sebagai Asas Tunggal bagi kekuatan-kekuatan politik dan organisasi-organisasi kemasyarakatan termasuk organisasi keagamaan. Wajar kalau penolakan itu berasal dari umat Islam. Bukan saja karena latar belakang sejarah yang pernah dilalui oleh mereka di era kontemporer Indonesia, melainkan juga karena pada saat Asas Tunggal itu dilontarkan, sub-sub Ideologi yang pernah ada di Indonesia terkena kebijakan Asas Tunggal itu. PPP yang merupakan fusi dari empat Pertai-partai Islam yaitu Parmusi, NU, PSSI, dan Perti yang masih berasaskan Islam akhirnya menerima Asas Tunggal.

Dengan pemberlakuan Asas Tunggal, sebagian umat Islam menganggap bahwa saluran aspirasi politik umat Islam telah hilang. Muncul kekhawatiran di kalangan sebagian mereka terhadap ancaman sekularisasi politik dan kehidupan sosial di Indonesia. Kekhawatiran ini muncul dari perasaan keberagamaan mereka. Ada anggapan bahwa dengan pemberlakuan Asas Tunggal bagi kekuatan politik dan dan organisasi kemasyarakatan, identitas keislaman mereka akan memudar. Amal usaha organisasi-organisasi keagamaan Islam pun dianggap sebagai sia-sia belaka karena tidak didasarkan pada Islam.

Untuk merumuskan situasi baru itu sekaligus memasyarakatkan kebijakan tersebut, beberapa kalangan yang sejak semula tidak melihat kemungkinan lain, menyelenggarakan forum-forum berkenaan dengan aspirasi Islam Indonesia kontemporer. Balitbang Agama Departemen (sekarang: Kementerian) Agama, untuk tujuan yang sama, meneyelenggarakan seminar dengan tema Peranan Agama dalam Pemantapan Ideologi Negara Pancasila. ${ }^{17}$ Kesimpulan dari kegiatan seminar itu nampaknya menyatakan bahwa aspirasi keagamaan dalam kehidupan politik tetap akan tersalurkan. Bahkan dengan kebijaksanaan yang dimaksudkan sebagai upaya modernisasi politik bangsa Indonesia menguntungkan umat Islam Indonesia karena mereka dapat melepaskan diri dari ikatan primordialisme. Banyak pemikir atau intelektual Islam yang beranggapan bahwa ditariknya Islam dari level politik, perjuangan kultural dalam pengertian luas menjadi relevan atau bahkan lebih efektif.

Sejak tahun 1970-an yakni awal masa Orde Baru kegiatan transformasi keislaman semakin berkembang bila dibandingkan dengan masa sebelumnya. Pada masa Orde Baru ini terlihat adanya

${ }^{17}$ Proyek Penelitian Keagamaan Balitbang Departemen Agama, "Peranan Agama dalam Pemantapan Ideologi Negara Pancasila” 1994/1995.

46 | TAJDID vol. XVI, No. 1, Januari - Juli 2017 
tanda-tanda kembangkitan Islam kembali. Fenomena yang jelas tentang sinyalemen ini dapat dilihat dari munculnya bangunanbangunan baru Islam misalnya masjid, mushalla, madrasah, dan pesantren. Munculnya bangunan-bangunan masjid yang megah misalnya diikuti pula dengan ramainya jamaah shalat terutama dari kalangan muda. Pengajian-pengajian keagamaan Islam juga marak. Departemen-departemen Pemerintahan mengadakan pengajian sendiri-sendiri. Bahkan pengajian dan diskusi keagamaan memasuki hotel-hotel mewah di kota-kota besar dan merekrut sebagai jamaah para pemuka bangsa. Ini mungkin dapat disebut sebagai kelanjutan proses islamisasi terhadap golongan abangan dan priyayi yang berpendidikan non Agama atau berpendidikan Barat.18 Ini adalah dinamika nyata transformasi Islam era Indonesia kontemporer. Ini merupakan masa maraknya Islam kultural dan Islam substantif. Ini pertanda nyata kebangkitan Islam.

Indikasi lain dari kebangkitan kembali Islam juga dapat dilihat di kampus-kampus Perguruan Tinggi. Sebagian besar kampus Perguruan Tinggi mempunyai masjid atau mushalla. Sepanjang hari perkuliahan, Organisasi Kemahasiswaan di kampus-kampus Perguruan Tinggi aktif menyelenggarakan kegiatan keagamaan. Apatah lagi di bulan Ramadhan marak menyelenggarakan kegiatan pesantren "kilat" dan kegiatan Ramadhan lainnya misalnya kegiatan sosial keagamaan, puitisasi al-Qur'an, derama atau pagelaran seni Islami, di samping shalat tarawih, tadarus al-Qur'an, serta kuliah keagamaan. Kegiatan yang serupa juga berlangsung di masjid-masjid yang diselenggarakan oleh para aktivis Remaja masjid dan bahkan oleh pegiat Karang Taruna. Indikasi kebangkitan Islam lainnya adalah banyaknya pelajar dan mahasiswa yang memakai busana muslim-muslimah, baik di Sekolah dan Perguruan Tinggi maupun di tempat-tempat umum. Demikiah pula, banyak kalangan selebritis, artis film dan penyanyi yang mendirikan atau aktif mengikuti pengajian-pengajian serta ceramah-ceramah keislaman.

Setelah pemimpin-pemimpin nasionalis Islam beberapa kali melewati batu sandungan politik mulai berubah secara perlahan. Mereka tidak lagi berusaha keras secara terbuka untuk membentuk Negara Islam, tetapi melakukan cara lain dengan berusaha melaksanakan beberapa unsur tertentu dari hukum Islam dan dakwah

${ }^{18}$ Nurcholish Madjid, "Islam In Indonesia: Challengs and Opportunities", dalam Mizan, No. 3, Vol. 1, 1984.

TAJDID Vol. XVI, No. 1, Januari - Juli $2017 \mid 47$ 
Islamiah. Beberapa tokoh Masyumi misalnya aktif dalam penyelenggaraan Lembaga-lembaga Dakwah. Misalnya M. Natsir sendiri memimpin DDII (Dewan Dakwah Islamiah Indonesia) sampai tahun 1993, Syafruddin Prawiranegara memimpin KMJ (Korp Muballighin Jakarta). Ada juga yang aktif di Perguruan Tinggi Islam Swasta, misalnya E. Z. Muttaqin aktif di UNISBA (Universitas Islam Bandung), Abdul Kahar Muzakkir aktif di UII (Universitas Islam Indonesia), dan lain-lain. Hal yang sama terjadi di kalangan NU. K. H. Ahmad Syaichu misalnya aktif memimpin Ittihadul Muballighin. Angkatan Muda NU pun banyak yang aktif di beberapa Lembaga Pengembangan Masyarakat dan ada juga yang mengembangkan Pesantren. Kebangkitan kembali Islam pada masa sekarang merupakan buah dari hasil kerja keras mereka.

Sejak tahun 1970-an juga banyak muncul intelektual muda dari kalangan Islam yang melontarkan ide dan pemikiran segar untuk masa depan umat. Kebanyakan dari mereka ialah intelektual muslim berpendidikan umum. Ini ada kaitannya sebagai buah dari kegiatan organisasi-organisasi kemahasiswaan Islam seperti HMI, PMII, dan IMM. Organisasi-organisasi kemahasiswaan Islam ini mengadakan kegiatan-kegiatan ilmiah secara intens sehingga menghasilkan kaderkader yang berpikiran maju secara inklusif dan substantif. Kemudian pemikiran-pemikiran mereka mempunyai peran dalam mentransformasikan Islam pada masa kontemporer Indonesia.

Namun satu hal yang tidak boleh dilupakan bahwa Departemen Agama (Kementerian Agama) yang dibentuk sebagai konsesi bagi umat Islam banyak berjasa dalam mendorong kebangkitan Islam pada masa kontemporer Indonesia. Banyak IAIN dan sebagian sudah berubah menjadi UIN serta banyak lagi STAIN yang berada di bawah naungan Departemen Agama berjasa dalam menyiapkan intelektual, guru-guru agama, da'i, dan muballigh dalam jumlah besar. Selanjutnya Departemen Agama secara terus menerus berupaya mengembangkan dan meningkatkanb IAIN serta STAIN. Ditambah dengan peranan Dapartemen Agama dalam membina madrasah-madrasah serta pesantren-pesantren di seluruh Indonesia. Kesemuanya itu berperan dalam mentransformasikan pemikiran Islam di era kontemporer Indonesia.

Selain itu, Yayasan Amal Bakti Muslim Pancasila yang dibina langsung oleh Peresiden pada masa itu patut diperhatikan. Yayasan ini banyak mendirikan masjid di banyak tempat di seluruh Indonesia yang banyak memberikan manfaat bagi penyebaran pemikiran Islam.

48 | TAJDID Vol. XVI, No. 1, Januari - Juli 2017 
Demikian pula dengan kebijaksanaan Pemerintah yang mendirikan MUI (Majelis Ulama Indonesia). MUI yang diisi oleh para intelektual muslim banyak memberikan pemikiran keislaman yang mencerahkan. Bahkan MUI berperan sebagai suatu forum pemecahan permasalahan keagamaan umat Islam Indonesia. Pun aspirasi keagamaan umat Islam dapat tersalurkan melalui lembaga ini.

Satu hal bahwa dengan penetapan Pancasila sebagai Asas Tunggal maka formalitas substansi wadah politik umat Islam dapat dikatakan hilang dari percaturan sosial politik. Namun dengan pembaharuan politik bangsa ini maka umat Islam terlepas dari ikatan yang sempit menuju dunia yang luas. Perjuangan kultural yang substansial adalah dunia yang luas dibandingkan dengan dunia politik saja. Kegiatan-kegiatan sosial dan kultural yang substantif mempunyai nilai yang lebih langsung menyentuh kepentingan bangsa dari pada hasil perjuangan politik.

\section{Transformasi Islam Era Reformasi}

Dengan keberhasilan gerakan reformasi tahun 1998 yang menandai berakhirnya era Orde Baru, maka umat Islam Indonesia sepatutnya secara aktif ikut dalam mentransformasikan Islam di era kontemporer Indonesia. Logika dalam suatu gerakan reformasi adalah merupakan koreksi terhadap berbagai keadaan yang sedang berlangsung untuk mendapatkan situasi dan kondisi yang lebih baik. Karena itu, suatu reformasi bukan dimulai dari titik nol, melainkan sebagai kelanjutan wajar dan alamiah dari tingkat kemajuan masyarakat dan dinamika perkembangannya. Maka pandangan yang ingin mempertahankan status quo dapat dipandang sebagai penghalang reformasi, karena pandangan itu adalah suatu bentuk pengingkaran terhadap logika perkembangan masyarakat yang terus bergulir dan maju. ${ }^{19}$ Dengan demikian maka peran transformasi Islam di era reformasi ini ialah untuk memperbaiki situasi dan kondisi umat Islam yang dianggap tidak kondusif menuju kemajuan umat Islam dan bangsa Indonesia secara keseluruhan ke arah cita-cita yang lebih baik.

Untuk transformasi Islam di era reformasi ini ke arah yang dicita-citakan, muncul wacana civil society yang digunakan secara luas di Indonesia setelah diperkenalkan oleh Anwar Ibrahim, yang waktu itu menjabat Menteri Keuangan dan Timbalan Perdana Menteri Malaysia,

${ }^{19}$ Nurcholish Madjid, Cita-cita Politik Islam Era Reformasi, (Jakarta: Penerbit Paramadina, 1999), 185.

TAJDID Vol. XVI, No. 1, Januari - Juli $2017 \mid 49$ 
dalam ceramahnya pada Festival Istiqlal di Jakarta. Di sini civil society diartikan sebagai masyarakat madani. Masyarakat madani adalah masyarakat bermoral yang menjaga keseimbangan antara kebebasan individu dan stabilitas masyarakat di mana masyarakat memiliki inisiatif individual yang tinggi. ${ }^{20}$

Memang istilah civil society merupakan produk budaya Barat, akan tetapi sebagai sebuah wacana transformasi Islam, cita-cita masyarakat yang didambakan seperti halnya yang terjadi di Barat tetap merupakan hal universal. Dalam hal ini masalah civil society merupakan aspek transformasi Islam sebagai suatu cita-cita ideal dari terciptanya bentuk kemitraan dengan tanggung jawab yang setara dalam masyarakat untuk memunculkan tatanan kehidupan sosial yang demokratis dan sistem ekonomi yang adil. Demokratisasi dan keadilan merupakan prasyarat penting untuk terwujudnya kesejahteraan dalam masyarakat multikultural dengan kesetaraan hubungan timbal balik serta kesediaan saling menghargai. Dalam Islam terdapat landasan transformasi Islam yang relevan di era sekarang tentang anjuran bagi seluruh umat manusia untuk saling mengenal dengan pengandaian adanya kesepahaman akan tugas dan posisi masing-masing. ${ }^{21} \mathrm{Jadi}$, civil society adalah bangunan masyarakat yang dicita-citakan dalam nuansa demokratis, Adil, makmur, dan sejahtera.

Pada awalnya muncul kesulitan untuk membumikan istilah civil society di masa kontemporer Indonesia dalam rangka transformasi Islam karena istilah ini berasal dari Barat. Segala sesuatu yang berbau ke Barat-Barat-an sering dianggap mempunyai ekses bahkan pengaruh negatif. Kemudian beberapa istilah dimunculkan untuk pengalihbahasaan istilah civil society yaitu misalnya istilah, "masyarakat sipil" atau "masyarakat warga". Bagi umat Islam Indonesia pernah pula dimunculkan istilah "masyarakat utama" yang merupakan padanan kata khairu ummah seperti yang tertulis dalam al-Qur'an. Istilah "masyarakat utama" mengandung masyarakat dinamis yang berada dalam spektrum perubahan sesuai dengan tuntutan zaman yang dianggap mempunyai semangat keislaman karena mengandung nilai-nilai Islami yang bersumber pada al-Qur'an dan Hadits. ${ }^{22}$ Istilah civil society mempunyai arti masyarakat berperadaban yakni masyarakat

${ }^{20}$ Hendro Prasetyo dan Ali Munhanif (dkk.), Islam dan Civil Society Pandangan Muslim Indonesia, (Jakaarta: Gramedia Pustaka Utama bekerja sama dengan PPIM IAIN Jakarta, 2002), 157.

${ }^{21}$ Hendro Prasetyo dan Ali Munhanif (dkk.), Islam dan Civil Society, 159.

${ }^{22}$ Hendro Prasetyo dan Ali Munhanif (dkk.), Islam dan Civil Society, 161. 
yang adil, makmur, dan sejahtera. Namun karena istilah ini berasal dari bahasa Barat maka muncul penolakan dalam penggunaannya. Kemudian ada usaha untuk pengalihbahasaan istilah civil society ke istilah lain misalnya masyarakat sipil, masyarakat warga, atau masyarakat utama agar dapat diterima secara luas dalam masyarakat. Namun istilah inipun tidak membumi sebagaimana yang diharapkan.

Dalam perkembangan selanjutnya muncul istilah "masyarakat madani" yang dapat dianggap sebagai pengalihbahasaan istilah sivil society. Kesamaan makna antara istilah "masyarakat madani" dan civil society dapat dilacak ke akar sejarah sosial Islam. Ini menunjukkan bahwa Islam memiliki landasan yang kuat dalam hal apa yang disebut civil society. Isltilah "masyarakat madani" lantas semakin dekat dengan istilah civil society dalam Agama Islam sehingga menghilangkan keraguan untuk menggunakan istilah civil society dalam transformasi Islam. Namun demikian pernah terjadi stigma intelektual dalam penggunaan istilah civil society dalam kaitannya dengan penggunaannya dalam sejarah sosial Eropa misalnya masyarakat borjuis, sekuler, dan liberalisme.

Memang istilah "masyarakat madani" dengan ciri khas keteladanan hidup masa Nabi Muhammad mempunyai nilai tersendiri dibanding dengan istilah civil society, karena istilah tersebut terakhir banyak didasarkan pada pengertian yang berasal dari konsep dan pengalaman Barat dalam arti nuansa agama yang minim sehingga belum mencapai tingkat civility. Namun demikian istilah penerapan civil society dapat dengan mudah ditemukan dalam tradisi dan sejarah Islam, karena ternyata Nabi Muhammad telah menjadikan masyarakat Madinah sebagai masyarakat madani seiring diwujudkannya mitsaq almadinah yakni Piagam Madinah. Rumusan Piagam Madinah memberikan justifikasi gambaran ideal tentang transformasi masyarakat Islam yang patut dilakukan di Indonesia era reformasi. Gagasan civil society sebagai istilah yang sepadan dengan "masyarakat madani" seharusnya menjadi pilihan dalam rangka transformasi Islam pada era sekarang. ${ }^{23}$

Piagam Madinah yang menjadi landasan "masyarakat madani" berisi perjanjian kerjasama dan saling melindungi serta saling

23 Nurcholish Madjid, "Potensi Sumber-sumber Doktrin Islam untuk Membangun dan Menanggapi Konsep Civil Society Modern" dalam Hasan Hanafi (dkk.), Islam dan Humanisme, (Yogyakarta: IAIN Walisongo Semarang - Pustaka Pelajar, 2007), 42.

TAJDID vol. XVI, No. 1, Januari - Juli 2017 |51 
membela antara berbagai kelompok agama yang berbeda - Islam, Kristen, Yahudi - yang merupakan dokumen pertama dalam sejarah peradaban manusia yang meletakkan dasar kemasyarakatan yang bersendikan pluralisme dan toleransi. Sebenarnya "masyarakat madani" yang digagas oleh Nabi Muhammad adalah reformasi total terhadap masyarakat Arab Jahiliah yang tidak mengenal hukum dan terhadap supremasi kekuasaan pribadi seorang penguasa dalam kepemimpinan masyarakat. ${ }^{24}$ Jadi, Piagam Madinah merupakan landasan atau laksana Undang-Undang Dasar yang menjadi titik tolak pijakan untuk membangun masyarakat yang adil, makmur, dan sejahtera.

Piagam Madinah meskipun belum sempurna seperti yang diinginkan oleh Nabi Muhammad namun semangat dan maknanya sering dijadikan rujukan oleh umat Islam dalam rangka transformasi Islam. Jadi, rujukan umat Islam di zaman kontemporer kepada masyarakat madani bukan ideologi yang mengada-ada tanpa alasan sejarah. Karena masyarakat madani yang dibangun oleh Nabi Muhammad, sebagaimana sering ditegaskan oleh Robert N. Bellah seorang sosiolog Agama Amerika, mempunyai sisi modernitas yang tinggi misalnya dalam hal komitmen, partisipasi masyarakat, dan suksesi kepemimpinan secara terbuka dengan menolak suksesi atas dasar keturunan misalnya seperti yang lazim terjadi dalam masyarakat sebelumnya. Salah satu bentuk pengaruh modernisasi masyarakat madani di Madinah ialah munculnya sistem pemerintahan kekhalifahan yang bermula dari ijtihad Umar bin Khaththab. Ini merupakan kelanjutan wujud pelaksanaan idealisme masyarakat madani yang diteladankan oleh Nabi Muhammad. ${ }^{25}$

Istilah masyarakat madani yang dalam bahasa Arab disebut almujtama' al-madani artinya ialah masyarakat berperadaban. Dalam bahasa Inggris yang sepadan dengan ini adalah civil society yang juga berarti masyarakat berkeadaban. ${ }^{26}$ Maka masyarakat madani adalah tatanan kehidupan suatu masyarakat yang mengacu pada kehidupan sosial yang berkualitas dan ber-tamaddun, civility. Masyarakat yang meniscayakan toleransi dan kesediaan setiap orang untuk menerima berbagai perbedaan pandangan dan sikap dalam tingkah laku sosial dan politik. Ini berarti tidak ada satu pihak pun termasuk pemerintah

${ }^{24}$ Hendro Prasetyo dan Ali Munhanif (dkk.), Islam dan Civil Society, 172.

${ }^{25}$ Hendro Prasetyo dan Ali Munhanif (dkk.), Islam dan Civil Society, 173.

${ }^{26}$ Hendro Prasetyo dan Ali Munhanif (dkk.), Islam dan Civil Society, 173.

52 | TAJDID Vol. XVI, No. 1, Januari - Juli 2017 
yang berhak memaksakan kehendak dan kemauannya sendiri baik dalam bentuk kooptasi maupun regimentasi yang akan menimbulkan kelumpuhan hukum dengan ongkos sosial yang mahal. ${ }^{27}$

Dalam transformasi Islam pada era kontemporer seyogiyanya tamaddun atau civility dijadikan dasar pemikiran. Tamaddun atau civility adalah dasar pijakan yang dapat dijadikan sikap kejiwaan untuk melihat segala sesuatu secara objektif. Dengan ini maka ada keberanian untuk melihat bahwa diri sendiri tidak selalu benar. Setiap orang atau kelompok harus menghindarkan diri dari sikap merendahkan orang atau kelompok lain karena yang merendahkan belum tentu lebih baik dari pada yang direndahkan.

\section{Kesimpulan}

Dari uraian di ata dapat dikemukakan bahwa transformasi Islam pada masa mutakhir Indoensia mengalami perkembangan yang pasang surut. Pada masa awal pendudukan Jepang umat Islam memperoleh kebebasa untuk melakukan transformasi Islam dalam bidang politik dan kemasyarakatan. Namun menjelang kemerdekaan Indonesia keadaan menjadi terbalik, peran trasformasi umat Islam menjadi sempit dibanding dengan peran yang diperoleh oleh golongan lainnya khususnya kalangan Nasionalis "sekuler".

Pertarungan ideologis transformasi Islam antara golongan Islam dan golongan Nasionalis "sekuler" tentang dasar negara muncul kembali dalam sidang Konstituante. Golongan Islam dalam rangka transformasi Islam kembali dikalahkan dengan keluarnya Dekrit kembali ke UUD 1945 sehingga Pancasila tetap sebagai dasar negara. Pada masa Orde Baru umat Islam kembali mengalami rintangan dalam memperjuangkan transformasi agamanya yaitu menjadikan Islam sebagai dasar negara bagi Indonesia. Pada masa ini bahkan diberlakukan Asas Tunggal Pancasila sehingga tidak ada kekuatan kekuatan politik dan organisasi sosial keagamaan Islam yang bercirikan Islam. Umat Islam banyak terlibat dalam memperjuangkan kemerdekaan negerinya dan bahkan turut menjadi korban dalam mepertahankan negerinya, namun tetap terpinggirkan sebagai pengambil kebijakan di negerinya sendiri. Maka Islam tidak pernah

${ }^{27}$ Nurcholish Madjid, "Islam dan Politik Suatu Tinjauan Atas Prinsipprinsip Hukum dan Keadilan", dalam Paramadina 1, no. 1, Juli-Desember 1998, 50. Hendro Prasetyo dan Ali Munhanif (dkk.), Islam dan Civil Society Pandangan Muslim Indonesia, (Jakaarta: Gramedia Pustaka Utama bekerja sama dengan PPIM IAIN Jakarta, 2002), 174.

TAJDID Vol. XVI, No. 1, Januari - Juli $2017 \mid 53$ 
benar-benar berada di puncak kepemimpinan nasional. Dengan demikian, berdasarkan situasi dan kondisi yang ada, maka langkahlangkah umat Islam dalam rangka transformasi Islam di Indonesia bergeser dari perjuangan Islam formalis dan struktural ke arah perjuangan Islam substantif dan kultural.

\section{Daftar Pustaka}

Abdullah, Taufik (ed.), Sejarah Ummat Islam Indonesia. Jakarta: MUI, 1991.

Abdurrahman, Moeslim. Islam Transformatif Pandangan Muslim Indonesia. (Jakarta: Pustaka Firdaus, 1997.

Almelz (ed.), HOS Tjokroaminoto Hidup dan Perjuangan. Jakarta: Bulan Bintang, 1952.

Anshari, Endang Saifuddin, Piagam Jakarta 22 Juni 1945. Bandung: Pustaka, 1983.

Boland, B. J., Pergumulan Islam di Indonesia. Jakarta: Grafitipers, 1985.

Clifford, Geerts. Santri Abangan dan Priyayi. Jakarta: Pustaka Jaya, 1980.

Legge, John D. Soekarno Sebuah Otobiografi Politik, Jakarta, S. H., 1985.

Madjid, Nurcholish, "Islam In Indonesia Challengs and Opportunies”, dalam Mizan, no.3, vol. 1, 1984.

------, Cita-cita Politik Islam Era Reformasi, Jakarta: Paramadina, 1999.

Nasution, Harun, Pembaruan dalam Islam. Jakarta: Bulan Bintang, 1975.

Noer, Deliar. Gerakan Modern Islam di Indonesia 1900-1942. Jakarta: LP3ES, 1980.

------, Partai-partai Islam di Pentas Nasional. Jakarta: Grafitipers, 1987

Prasetyo, Hendro dan Ali Munhanif (dkk), Islam dan Civil Society. Jakarta: Gramedia Pustaka Utama - PPIM IAIN, 2002.

Proyek Penelitian Keagamaan Balitbang Depag, Peranan Agama dalam Pemantapan Ideologi Negara Pancasila, 1994/1995

Tjokroamino, HOS., "Zelbestuur", dalam P. Soeharto dan S. Zinul Ihsan (ed.), Aku Pemuda Kemarin dan Hari Esok. Jakarta: Gunung Agung, 1982. 